\title{
"Legal and economic aspects of Ukrainian enterprises activity at the European renewable energy market"
}

\author{
Sergiy Bilotskiy \\ Nicole Danylova \\ AUTHORS \\ Olena Grinenko \\ Oleksandra Karmaza (D https://orcid.org/0000-0003-4895-5220 \\ Daria Koucherets
}

Sergiy Bilotskiy, Nicole Danylova, Olena Grinenko, Oleksandra Karmaza and

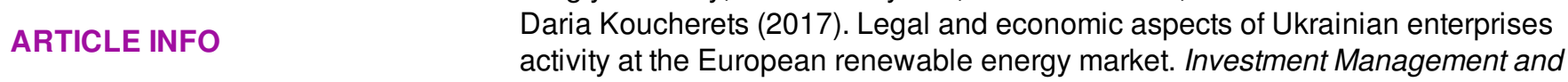
Financial Innovations, 14(2), 71-78. doi:10.21511/imfi.14(2).2017.07

DOI http://dx.doi.org/10.21511/imfi.14(2).2017.07

RELEASED ON

Friday, 02 June 2017

RECEIVED ON

Friday, 24 March 2017

ACCEPTED ON

Tuesday, 18 April 2017

\section{$((c))$ EY}

LICENSE

This work is licensed under a Creative Commons Attribution 4.0 International License

JOURNAL

"Investment Management and Financial Innovations"

ISSN PRINT

$1810-4967$

ISSN ONLINE

$1812-9358$

PUBLISHER

LLC "Consulting Publishing Company "Business Perspectives"

FOUNDER

LLC "Consulting Publishing Company "Business Perspectives"

NUMBER OF REFERENCES

20
NUMBER OF FIGURES

1
NUMBER OF TABLES

0

(C) The author(s) 2022. This publication is an open access article. 


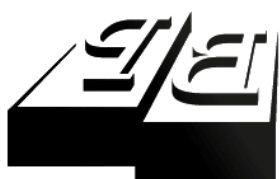

BUSINESS PERSPECTIVES

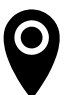

LLC "CPC "Business Perspectives" Hryhorii Skovoroda lane, 10, Sumy, 40022, Ukraine

www.businessperspectives.org

Received on: $24^{\text {th }}$ of March, 2017 Accepted on: $18^{\text {th }}$ of April, 2017

(C) Sergiy Bilotskiy, Nicole Danylova, Olena Grinenko, Oleksandra Karmaza, Daria Koucherets, 2017

Sergiy Bilotskiy, Doctor of

Law, Associate Professor of the Department of International Law, Institute of International Relations, Taras Shevchenko National University of Kyiv, Ukraine.

Nicole Danylova, Ph.D in Economics, Assistant Professor of the Department of International Economy and Marketing, Taras Shevchenko National University of Kyiv, Ukraine.

Olena Grinenko, Doctor of Law, Senior Researcher, Head of the Department of European Law and International Integration, Legislation Institute of the Verkhovna Rada of Ukraine, Ukraine.

Oleksandra Karmaza, Doctor of Law, Associate Professor, Professor of the Law Department, University of Modern Knowledge, Ukraine.

Daria Koucherets, Doctor of Law, Professor of the Law Department, University of Modern Knowledge, Ukraine.

\section{(ㄷ)(i)}

This is an Open Access article, distributed under the terms of the Creative Commons Attribution 4.0 International license, which permits unrestricted re-use, distribution, and reproduction in any medium, provided the original work is properly cited.
Sergiy Bilotskiy (Ukraine), Nicole Danylova (Ukraine), Olena Grinenko (Ukraine), Oleksandra Karmaza (Ukraine), Daria Koucherets (Ukraine)

\section{LEGAL AND ECONOMIC ASPECTS OF UKRAINIAN ENTERPRISES ACTIVITY AT THE EUROPEAN RENEWABLE ENERGY MARKET}

\begin{abstract}
The article deals with a current trend of the global energy market, which is characterized by rising tension in relations between the performers of the energy market regulation mechanisms, and it leads to the emergence of alternative energy sources. The article is called to identify the causes of renewable energy markets nascence, to make comparative description of Ukrainian and European Renewable Energy Markets attractiveness, and to characterize the state policy change in a renewable energy market. Different interpretation of nature and classification of the field of renewable energy in foreign and Ukrainian approaches shows the problem of legal criteria of renewable energy markets regulation. It is proved the existence of double barrier penetration of the European market for renewable energy for Ukrainian companies, which includes compliance with the accepted EU Directives and compliance with the Rules of each member individually. The presence of clearly defined standards and certificates of quality for the European market allows producers to show the competitiveness of Ukrainian products in the international market and stimulate Ukrainian manufacturers. The presence of clearly formulated laws, stable and balanced political and legal environment of the EU allows Ukrainian producers of renewable energy to develop such a strategy that considers the time factor, as the primary parameter of competitiveness in international business. The market of solid biofuels in EU is under formation, its development timeframe and uncertainty of environmental risks becoming is especially important for Ukrainian producers.
\end{abstract}

\section{Keywords}

renewable energy sources, energy consumption, energy efficiency, comparative analyses, economic expansion

\section{JEL Classification L16, K23, Q42}

\section{INTRODUCTION}

General problem statement. The current stage of the global economy development is characterized by increasing of long-term relationships and interpenetration of national economies of individual countries into a single global system and mutual influence on economic and social development within current system. Peculiarities of current stage of the world economy development are a significant population growth in the global scale and erratically increase of prosperities level around the world that globally actualizes the problem of energy supply and energy efficiency.

The current global energy sector situation is characterized by aggravation of relations between the major market participants: manufacturers $\leftrightarrow$ transitory $\leftrightarrow$ energy suppliers. Rising tension in relations between the performers of the energy market regulation mechanisms change the global energy market, which leads to the emergence of a new field of energy production, namely, the emergence of Alternative Energy Sources (AES). 


\section{ANALYSIS OF RECENT RESEARCH AND PUBLICATIONS}

In terms of increased interest in finding and using of alternative energy, renewable energy market became the subject of many studies of contemporary domestic and foreign scientists in different scientific areas, including A. Wane and D. Benny (2012), M. Kaltshmidt and W. Streicher (2007), W. Rau (2010), B. Sanner (2012), A. Dunn (2000) and others. Equally important is the contribution of native scientists who mainly explore the question of efficiency of renewable energy and consider the development of certain areas. In national literature in this field of research the known scientists are S. Alekseenko (2013), E. Andreev (2004), B. Baader (1982), A. Bashun (2012), A. Borodina (2008), M. Galitsyna, V. Geyets (2013), H. Heletukha (2005), V. Hnieushev (2002), S. Kudrya, L. Khmelnytsky (2010) and others.

Analyzing the study of modem economic literature to market alternative energy sources, a classification of approaches to the formulation of the essence (name) of the industry and its components can be proposed, in particular:

I. According to national approach (in Ukraine, Russia, Belarus, etc.), the term "alternative energy" / "alternative energy market" and "alternative energy sources" - are common for both scientific and practical interpretation on the former Soviet space. The components of "alternative energy" are (Alekseenko, 2013):

- renewable energy sources (solar, wind, geothermal and hydraulic energy, biomass, low potential heat of the earth, water, air);

- secondary sources of renewable energy (solid waste, heat from industrial wasted water, gas and heat ventilation);

- innovative technologies using non-renewable and renewable energy (oxygen energy, turbine in low energy, gasification and pyrolysis, catalytic combustion methods and processing of fossil fuels, synthetic fuels);
- power equipment (heat pump, Stirling's machine, steam and hydro turbine and equipment of direct energy conversion).

II. According to foreign approach (particularly in the US, the European Union), such terms as "renewable energy market" and "renewable energy sources" are used in foreign theory and practice in the analysis of market functioning of alternative energy sources. Renewable energy includes energy currents, power waves, solar, wind, hydropower, radiant energy, geothermal power, biomass, compressed natural gas, nuclear power (Top 10 Renewable Energy Sources, 2009).

Thus, different approaches demonstrate the difference in classification of alternative energy markets components. Foreign approach does not separate technology and equipment in the characteristics of renewable energy sources and summarizes the sources and methods of obtaining energy, while domestic approach clearly separates energy from unconventional sources into: direct sources, methods of energy production and technology.

However, along with the classic understanding of the concept of "alternative energy" in the modern economic literature there is the concept of "micro energetics" suggested by Seth Dunn of the Institute of World Environment (Worldwatch Institute) (Danilova, 2016). The scientist in this concept includes the following components: solar panels, wind turbines, hydrogen gas microturbine elements, lowpower electricity generators. Products of micro energetics according to $S$. Dunnan's theory are able to meet the demand for energy, which is particularly important for underdeveloped countries, where equipment using micro energetics, local industry and the public can access the power without waiting for the development of large plants and the national grid. The efficiency of modern micro energetics evidenced by significant investment from multinational companies, such as Swiss energy giant $\mathrm{ABB}$, which in 2013 invested $1.03 \mathrm{bn}$. USD into the development of renewable energy sources and small power plants to meet the consumer market (Danilova, 2016).

Nevertheless, the concept of "micro energetics" is too narrow for scientific research and is aimed at the practical aspects of life, designed for the production of specific equipment for the production of energy. 


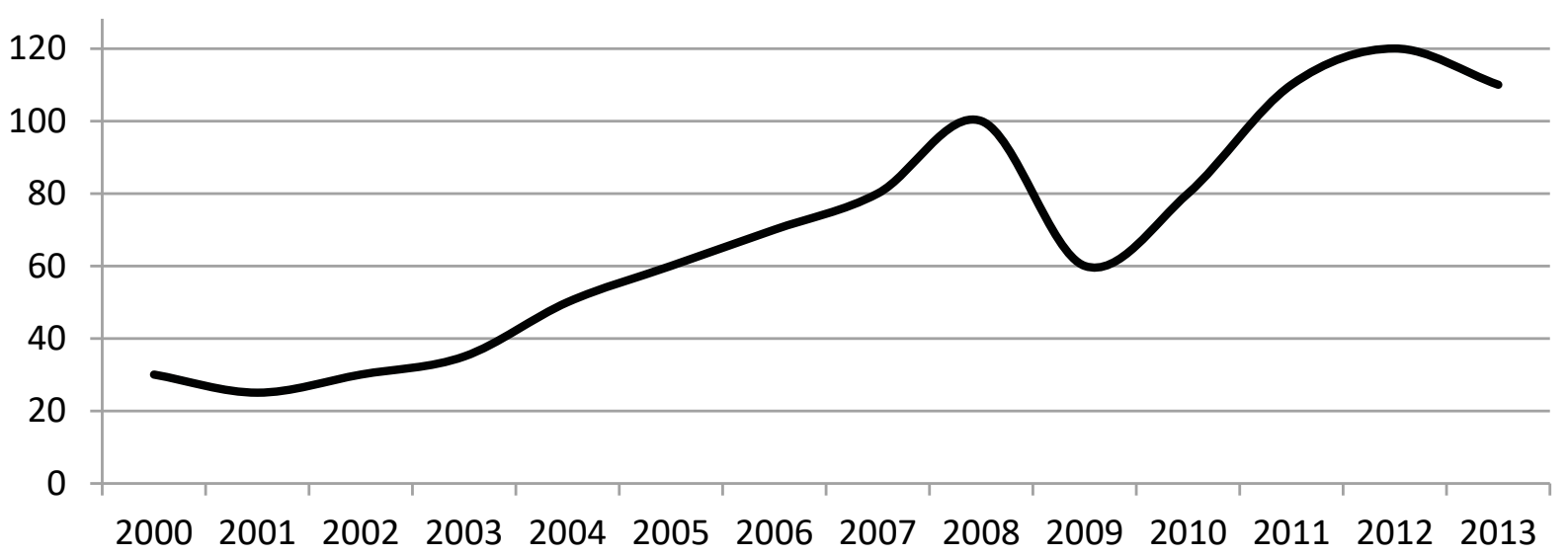

Oil price

Figure 1. Average oil price (\$ per barrel) (Index Mundi, 2014)

Despite the fact that every year more and more scientists study deeper into emerging market, the process of its formation is not finished and market trends require continuous research. The dynamics of the market development of renewable energy sources is becoming increasingly complex and hopping, so that the share of renewable energy in the global structure of energy production and consumption are unsustainable.

Given the different approaches to the nature of the industry and energy classification, the most appropriate use of terminology of peculiar western approach and the concept of "renewable energy sources" which are such resources that are recovered naturally and can be used again.

The aim of the article is to analyze the trends of the world energy market, identify the causes of renewable energy markets nascence, reveal strength in state regulation of the sector of renewable energy of the EU and weaknesses in Ukraine, to make practice recommendations for implementing methods of regulation in the renewable market of Ukraine.

\section{MAIN RESULTS OF THE RESEARCH}

The difference in the interpretation of nature and classification of the field of renewable energy in foreign and domestic approaches shows the problem of legal criteria of renewable energy markets regulation, the necessity for analysis of political and legal environment of the international market of renewables.

For during the last 20-30 years, demand for energy has increased by $30-50 \%$, leading to social and political instability, geopolitical conflicts and causing negative effects on the environment and climate. In addition, the population doubles every $40-50$ years, and the production and consumption increases in 2 times every 12-15 years (Ukraine pledged to get $11 \%$ of energy from renewable sources by 2020, 2012).

That is why, especially during the post-crisis adaptation, interest towards renewable energy started to grow. One of the main reasons for the market development of renewable energy is imbalance of the world's energy market in the period from 2003 to 2008, which was caused by the high rate of growth of the global economy and extremely high-energy demand (Figure 1).

Between 2003 and 2008 the average annual increase in world consumption exceeded $3.1 \%$, while in developing countries reached $6 \%$. Such dynamics of demand has led to the increase in the cost of all forms of energy produced from conventional sources, including the inability to increase supply, as the world oil market happened on a problem depletion of deposits, as well as a lack of investment capital due to the low level during its low prices for natural energy resources by 2002 . Even despite the recovery of the investment climate in 
the period from 2005 to 2008 , the cost of extraction of natural resources has grown and it significantly reduced the number of investment projects to the oil industry.

In addition, the 2008-2010 financial crisis and industrial and global recession had a significant influence on the global energy by slowing economic growth and demand for traditional energy sources, raising prices in the face of declining demand, the threats of demands refocusing on internal energy. Since the world economies have got out from the global financial crisis, the economic imbalance was gradually minimized, the scope of economic cooperation between two countries strengthened, which led to aggravation of geopolitical and social conflicts that manifest themselves at odds on the reorientation of approaches to the further development of the global society. Accordingly, a number of countries had to revise its energy strategy.

Thus, the main causes of imbalance in the energy sector (Danilova, 2016):

- objective and irreversible process of globalization;

- shortage of natural resources;

- unstable price of oil and gas, which tend to increase;

- strengthen of the relationship between producers, transit countries and consumers of energy resources;

- increasing competition for energy resources;

- high expenditure budget for transporting refined products;

- technological progress;

- increasing world population exponentially, which categorically leads to an increase in energy consumption;

- change in regional proportions of energy; insufficient investment in the energy sector;

- changing patterns of demand and the role of suppliers;

- $\quad$ significant increase in energy prices;

- increasing demand for transport energy needs;

- imbalance in the petroleum sector;

- environmental disaster and others.

The combination of these reasons leads to the fact that the role of renewable energy in the global structure continues to grow by promoting energy and environmental security, preservation of the environment. In addition, a new way to use natural sources of energy in developed countries (e.g., conservation of reserves in US domestic energy resources, increasing the consumption of raw materials for non-energy use of fuels) leads to faster growth and development of a new market - alternative energy sources.

Despite the fact that each year more and more scientists study deeper into emerging market, the process of its formation is not complete and market trends require continuous research. The dynamic of the renewable energy market is becoming more complex and hopping because the share of renewable energy in the global energy production structure is increasing or decreasing every time.

Specificity of the global renewable energy market is characterized by such factors (Danilova, 2016):

- limited resources with the use of traditional energy sources;

- the need to ensure access to cheap inputs and energy independence of members of the world market;

- environmental protection;

- meet the rapidly growing demand in the world market for energy sources and technologies. 
The usage of an alternative energy sources will let:

- $\quad$ save energy and improve energy efficiency, which is an important part of the package of measures needed to reduce greenhouse gas emissions;

- increase technological improvement;

- create opportunities for economic growth through innovation and a sustainable competitive energy policy;

- reduce its dependence on energy imports.

The transition to decentralized energy production has many benefits, including the use of local energy sources, increased energy security of supply, shorter transport distances and reduction of costs for power transmission, providing certainty for investors and stimulation of continuous development of technologies that generate energy from all types of renewable energy sources. Renewable energy is the fastest growing sector in the energy system and for many countries (US, EU, China, Brazil, Canada, etc.) is an important component of power supply.

Analysis of the dynamics of the global renewable energy market shows that despite the global economic crisis, deceleration of international trade, political uncertainty and reducing subsidies to the industry, the demand for renewable energy continues to grow. In most developed countries strategic plans are to increase the share of renewable energy in the total energy to $20-50 \%$ in the next 10-20 years (Danilova, 2016).

Considering the specific features of the international renewable energy market, which is at early stage of development and little competition, it's a real opportunity for Ukrainian companies to learn the newly created market. Also taking into account the rapidity of the industry, the Ukrainian producers have an additional opportunity to occupy a niche in the market. However, an important condition for the rapid development of the industry and for the fundamental choice is an effective market entry strategy. The process of expansion of economic activity in a market that is rapidly growing, selection of competitive behavior, taking into account the short period of entering and securing stable position - are characteristics of the most effective strategy for market penetration, namely economic expansion strategy.

Analysis of recent literature shows that there is currently no clear definition of "economic expansion". However, it should be noted that the definition of scientists from various fields of science, political science, law, economics, sociology and history (Ushakov, Komlev, Krysin, Borisov, etc.) resolve into considering the category of "economic expansion" as the expansion of economic impact, economic activities of the country, firms, corporations, monopolies, economic relations, accompanied by aggressive behavior of invasive measures aimed at economic, political or other conquest.

Considering the above, it is proposed to generalize definition:

"Economic expansion" - is a strategy of entering international markets, which provides a rapid (aggressive or less aggressive) coverage of significant market share for gaining the leadership.

This form of international economic relations is undoubtedly the most effective for reaching the market, which is under development. That is the alternative energy market of the European Union. In support of its appeal the analysis of market factors affirms:

1. Political and legal factors. In EU countries it's formed - the legal framework in the field of alternative energy, there is support from European industry defined standards certification and so on.

2. Economic factors. The EU member states are characterized by incease prices for traditional energy resources, multi-million investments in the alternative energy sector, significant market potential, high cost of transportation of gas and oil.

3. Natural factors. These ones include shortage of natural energy resources, environmental safety, and favorable climatic conditions in the territory of the member states. 
4. Scientific and technological factors. For the EU member states having highly qualified specialists in the field of alternative energy sources and the use of new developments (Danilova, 2012) is typical.

However, despite the transformation of UkraineEU relations under the influence of changes in the international political climate in 2014 (the possibility of the introduction of the Free Trade Agreement), the most important aspect when entering the EU market is a comparative analysis of the political and legal environment, which plays a key role in determining of the prospects for international cooperation of economic performers and priorities of Ukrainian companies in terms of European political and legal system, implementation of strategies and business penetration behavior of Ukrainian producers in terms of the European market. Political and legal environment in the EU affects the economic development of member states and creates the possibility of using different construction principles of business strategies for foreign companies now entering the market. The main purpose of the analysis of the political and legal environment is studying of the characteristics of political and legal system, determining of the status of legal and political stability and legal impact on the intensity of the business sector and score political and legal risks.

The general analysis of EU energy legislation can provide some basic principles of EU energy policy that have a significant impact on the decision of Ukrainian manufacturers to enter the EU market:

- principle of non-discrimination that energy market means a ban on disconnection of discriminatory conditions in contracts for the supply and enables the "Third Party" (Ukrainian producers) to market;

- principle of transparency that characterizes the transparency of the situation on the domestic market, the ability to obtain information about the level of consumer energy prices, as well as monitoring of the Union for the supply and transit of energy that enables transparent entry to Ukrainian producers of renewables and guarantees quality assurance of products to consumer;
- principle of not causing harm to the environment, that is reflected by the availability of appropriate certificates from Ukrainian producers and compliance with the European market of renewable energy sources;

- principle of taking into account the social factors in energy policy, which is showing interest of Ukrainian companies in enhancing of social importance of renewable energy and promotion of ecological energy in the population (Bilotskyi, 2012).

Above-mentioned principles are aimed at ensuring stability of supply, energy efficiency and development of renewable energy. For Ukrainian producers of energy from renewable sources, a consolidated list of principles of the EU energy market is the ability to use the strengths of the European market for its development, including the generated demand by consumers, strong government support for producers of alternative energy, available financial possibilities of using renewable energy sources by consumer and industrial sector of EU, cultural factors of support of environmental energy consumption.

In order to support renewable energy market of the European Commission it has been developed the Directive 2009/28/EC "on the promotion of supplying energy from renewable sources". This directive established the principle of "20-20-20": by 2020 , saving $20 \%$ of primary energy consumption, greenhouse gas emissions, as well as an increase of $20 \%$ share of renewable energy in total consumption.

An important feature of the Directive 2009/28/EC is the possibility of EU to cooperate with the third countries on renewable energy under the following conditions:

- electricity must be supplied in EU;

- electricity must be produced using the latest equipment (after June 2009);

- export of produced electricity must not use subsidies. 
According to this decision Albania, Bosnia and Herzegovina, Croatia, the Former Yugoslav Republic of Macedonia, Kosovo, Moldova, Montenegro, Serbia and Ukraine have undertaken the obligatory share of renewable energy in the total consumption in 2020. The shares were calculated based on the methodology of the EU: Albania - 38\%, Bosnia and Herzegovina - 40\%, Croatia - 20\%, the former Yugoslav Republic of Macedonia - 28\%, Moldova - 17\%, Montenegro $33 \%$, Serbia $-27 \%$, Ukraine $-11 \%$ and Kosovo $25 \%$ (Ukraine pledged to get $11 \%$ of energy from renewable sources by 2020, 2012), in Turkey (Gökgöz, 2016).

Considering the commitment of Ukraine to increase the use of renewable energy to $11 \%$ by 2020 and stimulate domestic market for Ukrainian companies involved in the renewable energy market, the provisions of Directive 2009/28/EC provide the opportunity to reach the competitiveness of Ukrainian domestic products and take share of the European mar- ket. However, it is necessary to draw attention to the existence of double barrier penetration of the European market for renewable energy for Ukrainian companies, which includes compliance with accepted norms and rules of the EU Directive and compliance with the Rules of each member individually. The analysis of the political and legal environment of the European Union provides the following conclusions that the presence of clearly defined standards and certificates of quality for the European market allows producers to show the competitiveness of Ukrainian products in the international market and stimulate Ukrainian manufacturers to improve product quality, to invest in innovative methods and the newest equipment that positively appears on the satisfying generated demand in the EU market. The presence of clearly formulated laws, stable and balanced political and legal environment of the EU allows Ukrainian producers of renewable energy to develop a strategy of economic expansion of the European market of renewable energy.

\section{CONCLUSION}

Modern transformation of the world economy under the influence of intensifying international competition lead to minimize the period of release companies into new markets, as in the proposed strategy for economic expansion to enter the international market, which involves the selection of certain forms of exit (export, joint venture, private equity), instruments (marketing, finance, internal organization) and the principles of competitive behavior (aggressive, moderate, loyal).

Strengthening of Ukraine's integration into European economics and transformation of the global energy market trends revealed the formation of solid biofuels in the EU, including the acceleration of scientific progress and international energy cooperation in the field of energy; increase market capacity of renewables; growth in investment in the sector; strengthen public policy in favor of EU environmental alternatives to find modern energy; the emergence of new sources of funding and regulatory institutions sector; enhance energy independence countries.

During the analysis it is proved significant in political and legal environment as solid biofuel industry support from the European Parliament, certification requirements, the availability of a stable legal framework regulating the field of solid biofuels, intensification of Ukrainian-European relations, strained relations with EU major energy supplier.

Regulation instruments of renewable sources market of Ukraine can be improved within the implementation of effective regulatory tools in EU. 


\section{REFERENCES}

1. Alekseenko, S. (2013). Nanochasti si prinesut mnoho polzy. Elektroenerhetika: sehodnia $i$ zavtra - Electricity: today and tomorrow, 5, 18-25.

2. Andreev, E. I. (2004). Osnovy estestvennoi enerhetiki. Saint-Petersburg: Nevskaia Zhemchuzhina.

3. Baader, B. (1982). Biohaz. Teoriia praktika. Moscow: Colossus.

4. Bashun, A. (2012). Katehoriia alternativnykh dzherel enerhii $v$ mizhnarodnomu pravi 21 stolittia, 93-100.

5. Bilotskyi, S. D. (2012). Rol mizhnarodnoho prava u rozvytku ekolohichnoi alternatyvy sychasnii enerhetitsi. Proceedings from the collection materials of International Scientific Conference '12: Mizhnarodna naukova konferentsiia "Rol mizhnarodnoho prava u rozvytku ekolohichnoi alternatyvy sychasnii enerhetitsi" International Scientific Conference "The role of international law in the development of environmental alternative to modern energy", Kyiv:"Fenix", 130-131.

6. Borodina, A. (2008). Vidnovliuvana enerhetika perspektyvy dlia silskoho hospodarstva. Propoziziia - Offer, 10, 90-94.

7. Dana, Meachen Rau. (2010). Alternative Energy: Beyond Fossil
Fuels. Mankato, MN: Compass Point Books.

8. Danilova, N. V. (2012). International strategic economic partnership between Ukraine and EU on renewable energy market: the nature and direction. Foreign trade, economics, finance, law, 4 , 57-60.

9. Dunn, A. (2000). Photovoltaics Hong-Kong's renewable energy source. Hong Kong Papers in Design - Volume One.

10. Heiets, V. M., \& Hrytsenko, A. A (2013). Vyhid z kryzy (rozdumy nad aktualnym y zviazku z prochytanym). Ekonomika Ukrainy - Economy of Ukraine, 6, 4-19.

11. Danilova, N. V. (2016). The Strategies Of Ukrainian Companies For Entering The EU Solid Biofuels Market (Doctoral dissertation). Retrieved from Dissertations and Theses. (Accession Order DK No. 035553).

12. Hnieushev, V. (2002). Torhovi resursy v Ukraini i shliakhy ikh vykorystannia. Alternatyvni ta vidnovliuvani dzherela Alternative and Renewable Energy, 22-27.

13. Index Mundi. indexmundi.com Retrieved from http://www. indexmundi.com/commodities/? commodity $=$ crude-oilbrent\&months $=360$
14. Gökgöz, F., Filiz, F. (2016). Electricity price forecasting in Turkey with artificial neural network models. Investment Management and Financial Innovations, 13(3), 150-158.

15. Kaltschmitt, Martin, Streicher, Wolfgang, \& Wiese, Andreas. (2007). Technology, Economics and Environment. Berlin: SpringerVerlag Berlin Heidelberg.

16. Khmelnytsky, L. (2010). Renewable energy sources usage as mechanism for overcoming disparities in macroeconomic development. Renewable Energy Problems, 3, 25-34.

17. Sanner, B. (2012). EU sustainable energy week. Energy - EGEC.

18. Top 10 Renewable Energy Sources. listverse.com. Retrieved from http://listverse. com/2009/05/01/ top-10-renewable-energy-sources/

19. Wayne, W. Fish, Benny, D. Bruton, \& Vincent M. Russo. (2012). Watermelon juice: a promising feedstock supplement, diluent, and nitrogen supplement for ethanol biofuel production. Biotechnology for Biofuels. The Article is a work of the United States Government - 24, Aug 2009.

20. Ukraina zoboviazalasia otrymaty $11 \%$ enerhii $z$ vidnovliuvanykh dzherel do 2020. ua-energy.org. Retrieved from http://ua-energy. org/post/25571 